WITALIJ ROSOWSKI* - LUBLIN

\title{
KONFISKATA KOSZTOWNOŚCI KOŚCIELNYCH W 1922 ROKU A KOŚCIÓŁ RZYMSKOKATOLICKI NA PODOLU SOWIECKIM
}

Władza radziecka praktycznie od swoich pierwszych dekretów regulujących sprawy wyznaniowe pozbawiła Kościół prawa własności oraz upaństwowiła cały jego majątek. W praktyce jednak wywłaszczenie tak ogromnego mienia nie było sprawą prostą. $Z$ jednej strony akcja ta wymagała czasu i przygotowań, ze względu na ogromną liczbę świątyń ${ }^{1}$, z drugiej - partia bolszewicka, w obawie przed masowym wystąpieniem ze strony wiernych i duchowieństwa $\mathrm{w}$ obronie swoich kościołów, wyczekiwała na dogodną chwilę. Okazją tą stał się głód, który na początku lat dwudziestych ogarnął Powołże, Kaukaz oraz południe Ukrainy. Wykorzystując to Centralny Komitet Wykonawczy w Moskwie wydał 23 lutego 1922 roku dekret „O trybie przejęcia kosztowności pozostających w użytkowaniu wspólnot religijnych"2. Postanawiał on niezwłocznie przystąpić do konfiskaty wszystkich kosztowności kościelnych oraz przekazanie ich przez Ludowy Komisariat Finansów do specjalnego funduszu Centralnego Komitetu Pomocy Głodu-

* Witalij Rosowski - dr historii, asystent w Instytcie Badań nad Polonią i Duszpasterstwem Polonijmym KUL.

1 Tylko na terytorium Ukrainy radzieckiej przed 1917 rokiem było 12380 budynków modlitewnych różnych wyznań. Zob. Русская Православная Церковь и коммунистическое государство 1917-1941. Документы и материаль, Москва 1996, s. 301.

${ }^{2}$ Русская Православная Церковь в советское время (1917-1991). Материалы и документы по истории отнотений между государством и Церковью, ред. Г. Штриккер, кн. 1, Москва 1995, s. 148; J. Jarco, Kalendarium Sacrum Russiae Millennium, w: Dar Polski Białorusinom, Rosjanom i Ukraińcom na Tysiąclecie ich Chrztu Świętego, red. K. Podlaski, Londyn 1989, s. 74; Б. Змерзлый, Изъятие церковных иенностей. Некоторые аспекты проблемы, „Культура народов Причерноморья", 3 (1998) s. 138. Niektórzy podają datę publikacji 26 lutego 1922 roku. Zob. Русская Православная Церковь и коммунистическое государство, s. 68; Б. Чаплицкий, И. Осипова, Книга памяти. Мартиролог католической Церкви в СССР, Москва 2000, s. XXVIII; R. Dzwonkowski, Kościót katolicki w ZSSR 1917-1939. Zarys historii, Lublin 1997, s. 129. 
jącym (dalej cyt.: CKPG) ${ }^{3}$. Prawdziwe cele tej konfiskaty były jednak zupełnie inne, a ich rzeczywiste oblicze ukazuje ściśle tajny list Włodzimierza Lenina do członków Biura Politycznego Rosyjskiej Komunistycznej Partii (bolszewików) z 19 marca 1922 roku$^{4}$. Między innymi pisał, że „możemy (i dlatego powinniśmy) przeprowadzić konfiskatę kosztowności kościelnych z najbardziej gwałtowną i bezwzględną energią i nie zatrzymywać się przed stłumieniem jakiegokolwiek sprzeciwu” [...], ,tym samym możemy otrzymać dla siebie fundusz w kilka setek milionów złotych rubli”, które można wykorzystać we własnych interesach wewnątrz kraju, jak i dla umocnienia swojej pozycji na arenie międzynarodowej. Dlatego, mówił dalej, „musimy teraz wydać stanowczą i bezlitosną walkę skrajnie reakcyjnemu duchowieństwu i zdławić jego sprzeciw z takim okrucieństwem, aby oni nie zapomnieli tego w ciągu najbliższych dziesięcioleci"s. W rzeczywistości dekret ten stał się dla władz dogodnym pretekstem do ataku na Kościół $1^{6}$.

W obronie rabowanych kościołów ostro wystąpił abp Jan Cieplak, który kategorycznie zabronił swoim księżom wydawania inwentarzy kościelnych ${ }^{7}$. Po rozpoczęciu w marcu 1922 roku konfiskat kosztowności kościelnych, trzykrotnie wystosowywał on do Ogólnorosyjskiego Centralnego Komitetu Wykonawczego notę protestacyjną, żądając wstrzymania rekwizycji w kościołach oraz zwrotu już skonfiskowanego mienia ${ }^{8}$. Abp Cieplak prosił również władze o zgodę na porozumienie się w tej sprawie ze Stolicą Apostolską ${ }^{9}$. Te działania arcybiskupa sprawiły, że wobec niego, zgodnie z poleceniem z Moskwy, wszczęto śledztwo pod zarzutem zakłócenia dekretu o konfiskacie kosztowności kościelnych i podburzania wiernych do sprzeciwu wobec tej akcji ${ }^{10}$. Władza natomiast nie zważała na

${ }^{3}$ Русская Православная Церковь и коммунистическое государство, s. 68; Русская Православная Церковь в советское время, кн. 1, s. 148.

${ }^{4}$ Русская Православная Церковь и коммунистическое государство, s. 88-92; О. А. Лиценбергер, Римско-католическая Церковь в России. История и правовое положение, Саратов 2001, s. 233-235 (autorka zamieszcza w swojej pracy obszerne fragmenty tego listu); В. Пащенко, Богоборча політика комуністичної партії та примусова атеїзація населення у контексті здійснення свободи совісті в 1920-1930 роки, w: Свобода віровизнання. Церква і держава в Україні. Матеріали міжнародної наукової конферениії. Київ, 28-30 вересня 1994 р., Київ 1996, s. 37.

${ }_{5}^{5}$ Por. Русская Православная Церковь и коммунистическое государство, s. 89-90.

${ }^{6}$ Dzwonkowski, Kościót katolicki w ZSSR, s. 129.

${ }^{7}$ Dzwonkowski, Kościót katolicki w ZSSR, s. 129; F. Sznarbachowski, Początki i dzieje Rzymskokatolickiej Djecezji Łucko-Żytomierskiej, obecnie Łuckiej, w zarysie, Warszawa 1926, s. 239; H. Stehle, Tajna dyplomacja Watykanu. Papiestwo wobec komunizmu (1917-1991), Warszawa 1993, s. 34; Лиценбергер, Римско-католическая Церковь в России, s. 229-230.

${ }^{8}$ Wspomniane protesty hierarchy katolickiego z Piotrogrodu zachowały się w Państwowym Archiwum Rosyjskiej Federacji (ф. А-353, оп. 6, д. 6, к. 30-31; д. 9, к. 67, 87). Pierwszy z nich pochodził z 22 kwietnia 1922 roku, a kolejne z 18 maja i 20 czerwca 1922 roku. Por. Архивы Кремля. Политбюро и Церковь 1922-1925 г2., ред. Н. Н. Покровский, С. Г. Петров, Москва 1997, s. 503.

${ }^{9}$ Zob. Dzwonkowski, Kościót katolicki w ZSSR, s. 130.

${ }^{10} \mathrm{O}$ aresztowanie arcybiskupa Jana Cieplaka i powstrzymanie jego „przestępczej działalności” przeciwko władz bolszewickich dwukrotnie wnosił do wydziału sprawiedliwości Piotrogrodzkiego 
żadne protesty i nadal kontynuowała rekwizycje, które wkrótce objęły większość kościołów katolickich.

Kampania ta nie ominęła również Kościoła katolickiego na Ukrainie radzieckiej, w tym też na Podolu, gdzie katolicy w porównaniu z innymi wyznaniami stawiali największy opór. Szczególnie w niektórych kościołach diecezji kamienieckiej ${ }^{11}$ przybrał on formę zdecydowanego sprzeciwu ze strony wiernych i duchowieństwa, którzy bronili swoich świątyń. W konsekwencji pociągnęło to za sobą ostrą reakcję miejscowych władz, włącznie z aresztowaniem i uwięzieniem osób przeciwstawiających się rekwizycjom.

W ślad za dyrektywą Komitetu Centralnego Rosyjskiej Komunistycznej Partii (bolszewików) centralne wykonawcze władze na Ukrainie podjęły uchwałę z 8 marca 1922 roku „O przekazaniu kosztowności kościelnych na fundusz pomocy głodującym". WUCWK ${ }^{12}$ zarządził, aby miejscowe Rady w ciągu najbliższego miesiąca skonfiskowały w cerkwiach, kościołach, synagogach i innych budynkach sakralnych wszystkie wartościowe przedmioty z platyny, złota, srebra, kamieni szlachetnych oraz kości słoniowej, które znacząco nie wpłyną na sprawowanie kultu i przekazały te kosztowności na fundusz CKPG. W tym celu należało w każdej guberni zorganizować specjalne komisje pod kierownictwem jednego z członków WUCWK, w składzie przedstawicieli miejscowego komitetu wykonawczego, komitetu pomocy głodującym oraz urzędu finansowego. $\mathrm{W}$ dokumencie tym również wspomniano o sankcjach ${ }^{13}$, jakie groziły za ukrywa-

Gubernialnego Komitetu Wykonawczego P. Krasikow, kierownik V wydziału Ludowego Komisariatu Sprawiedliwości. Na tej podstawie pod koniec maja 1922 roku wszczęto śledztwo przeciwko arcybiskupowi, który miał do czasu sądu pozostawać w Piotrogrodzie. W niespełna rok później sprawa ta została włączona, jako jedna z części oskarżenia, w słynnym procesie moskiewskim przeciwko abpowi Cieplakowi i innym kapłanom katolickim. Zob. Архивы Кремля, s. 503-504. Szerzej o przebiegu procesu i pobycie w więzieniu arcybiskupa zob. F. Rutkowski, Arcybiskup Jan Cieplak (1857-1926). Szkic biograficzny, Warszawa 1934, s. 228-294.

${ }^{11}$ Papież Benedykt XV w 1918 roku restytuował diecezję ze stolicą w Kamieńcu Podolskim oraz mianował jej ordynariuszem byłego proboszcza kościoła katedralnego księdza Piotra Mańkowskiego. Pod koniec I wojny światowej biskupstwo kamienieckie, obejmujące swymi granicami ówczesną gubernie podolską, liczyło 10 dekanatów, 112 kościołów parafialnych i filialnych, 106 kaplic oraz około 130 księży i prawie 320 tysięcy wiernych. Elenchus ecclesiarum et universi cleri dioecesium Luceoriensis et Żytomiriensis nec non Camenecensis, Anno Domini 1918, Żytomiriae 1918, s. 54-80. Poczynając od początku lat dwudziestych bp Mańkowski wraz z większością duchowieństwa diecezjalnego znalazł się na uchodźstwie w Polsce i zamieszkał na terenie archidiecezji lwowskiej. Terytorium biskupstwa w całości znalazło się pod rządami bolszewickimi. Na Podolu sowieckim pozostało wówczas niespełna 50 kapłanów. Zob. Elenchus omnium ecclesiarum et universi cleri dioecesis Camenecensis, Pro Anno Domini 1924, [Buczacz 1924], passim.

${ }^{12}$ Всеукраїнський Центральний Виконавчий Комітет (Ogólnoukraiński Centralny Komitet Wykonawczy).

${ }^{13}$ Zgodnie z tą uchwałą za ukrywanie kosztowności kościelnych i opisów inwentarzowych groziła kara do jednego roku robót przymusowych z konfiskatą całego majątku organizacji religijnych. W późniejszym okresie kary zostały znacznie zaostrzone. Za wspomniane przewinienia 
nie kosztowności kościelnych ${ }^{14}$. Z kolei sposób, w jaki należało przeprowadzać konfiskatę tych kosztowności, bardzo szczegółowo określała osobna instrukcja WUCWK z 21 marca 1922 roku. Zalecała ona miejscowym komisjom, aby na podstawie inwentarzy kościelnych sprzed 1917 roku, ustaliły porządek przeprowadzenia konfiskat $\mathrm{w}$ zależności od ilości kosztowności znajdujących się w poszczególnych kościołach. Komisje miały jednak bezzwłocznie przystąpić do tej akcji w najbogatszych świątyniach, nie czekając na zbiór opisów inwentarzowych $\mathrm{z}$ całej guberni. Skonfiskowane rzeczy należało dokładnie spisywać, a w wypadku braku jakichkolwiek kosztowności sporządzać protokół i sprawę przekazać dla wyjaśnienia organom śledczym. Przedstawicieli danej wspólnoty religijnej mieli też prawo do oprotestowania konfiskaty niektórych przedmiotów potrzebnych do sprawowania liturgii z możliwością zamiany ich na mniej cenne. Bez wyjątku natomiast podlegały konfiskacie przedmioty mające wartość muzealną. Wszystkie kosztowności należało przesyłać do funduszu CKPG. Lokalne organy władzy zobowiązano też, aby co miesiąc wysyłały do centrali dokładne informacje o przeprowadzonej pracy i ilości skonfiskowanych kosztowności ${ }^{15}$.

Cała ta akcja była przeprowadzana pod ścisłą kontrolą $\mathrm{WUCzK}^{16}$, która, rozsyłając różnego rodzaju dyrektywy do poszczególnych guberni, czuwała nad skutecznością i dokładnością konfiskat. Gubernialne CzK na Podolu już pod koniec marca otrzymało zalecenie, aby kategorycznie nie dopuszczać do zamiany kosztowności kościelnych przez wiernych na produkty żywnościowe. W wyjątkowych wypadkach mogła nastąpić jedynie zamiana niektórych kosztowności na ekwiwalent w złocie lub srebrze. WUCzK doradzała też konfiskatę rozpoczynać od najbogatszych i przyjaźnie nastawionych parafii w miastach, a później przechodzić do poszczególnych wsi ${ }^{17}$. Wynika z tego, że władzy radzieckiej wcale nie chodziło o pomoc dla głodujących, lecz przede wszystkim o znalezienie środków materialnych do zasilenia budżetu i skarbu państwa. W tym miejscu należy zwrócić uwagę na jeszcze jedną ściśle tajną instrukcję z dnia 27 marca 1922 roku, która miała służyć jako wytyczna dla komisji do spraw konfiskaty kosztowności kościelnych. Dokument ten dokładnie określał jakie cenne przedmioty kościelne podlegały konfiskacie ${ }^{18}$. Miejscowe komisje jednak bardzo często nie zwracały na niego uwagi i konfiskowały wszystko, co mogło stanowić jakąkolwiek wartośćc ${ }^{19}$.

groziło od roku do 5 lat pozbawienia wolności, a nawet kara śmierci. Por. Державний Архів Вінницької Області (dalej: ДАВО), Р-925, оп. 2, спр. 592, k. 149.

${ }^{14}$ Tamże, Р-835, оп. 1, спр. 354, k. 5.

${ }^{15}$ ДАВО, Р-835, оп. 1, спр. 354, k. 2, 27; Р-925, оп. 2, спр. 878, k. 6-7.

${ }^{16}$ Всеукраинская Черезвычайная Комиссия по борьбе с Контрреволюцией и Саботажем (Ogólnoukraińska Nadzwyczajna Komisja do Walki z Kontrrewolucją i Sabotażem), (1917-1922).

17 ДАВО, Р-925, оп. 2, спр. 878, k. 32; оп. 8, спр. 82, k. 24.

${ }^{18}$ Tamże, Р-587, оп. 1, спр. 81, k. 4; Р-925, оп. 2, спр. 878, k. 45.

${ }^{19} \mathrm{~W}$ czasie rekwizycji łupem bolszewików stawały się nie tylko kosztowności kościelne, jak to kielichy mszalne, monstrancje, cyboria, lichtarze, lampy, świeczniki czy kadzielnicy, ale i inne rzeczy: różnego rodzaju sprzęty, meble, obrazy, chorągwie, bielizna kościelna, dywany itp. Por. Archiwum Polskiego Instytutu i Muzeum im. gen. Sikorskiego w Londynie (APIS), sygn. A. 12. 
Po otrzymaniu powyższych dyrektyw miejscowe władze wykonawcze na Podolu dnia 30 marca 1922 roku powołały własną gubernialną komisję do spraw konfiskaty kosztowności. W jej skład weszli kierownik wydziału finansowego, jako czasowy przewodniczący oraz dwóch członków w osobach przewodniczących gubernialnej CzK i komisariatu wojskowego ${ }^{20}$. W ciągu najbliższych dni komisja rozesłała do wszystkich powiatowych komitetów wykonawczych specjalne rozporządzenia o niezwłocznym zorganizowaniu na miejscach komisji i rozpoczęciu pracy $^{21}$.

Bezpośrednie przystąpienie do rekwizycji kosztowności kościelnych poprzedzała zakrojona na szeroką skalę kampania agitacyjna, która miała objąć całą gubernię w celu odpowiedniego przygotowania wiernych i duchowieństwa do dobrowolnego oddawania kosztowności kościelnych ${ }^{22}$. Akcją propagandową, którą planowano skończyć przed 10 kwietnia, na prośbę komisji kierował gubernialny komitet partyjny ${ }^{23}$. Do tej pracy zostali włączeni najlepsi partyjni aktywiści ${ }^{24}$. Jedną z głównych ról w kampanii informacyjno-agitacyjnej odgrywała prasa ${ }^{25}$. Pod koniec kwietnia gubernialna komisja na Podolu z dumą powiadamiała władze w Charkowie, iż w ciągu lutego-kwietnia w gazetach opublikowano 40 artykułów, 60 telegramów, 39 notatek oraz 4 postanowienia w sprawie rekwizycji kosztowności kościelnych ${ }^{26}$. Poza tym w poszczególnych miejscowościach organizowano wiece i zgromadzenia przedstawicieli duchowieństwa i wiernych różnych wyznań, na których podejmowano uchwały w sprawie konfiskaty kosztowności w celu pomocy głodującym ${ }^{27}$.

P/6/4/35, k. 196-197; Kościót katolicki na Ukrainie (1917-1923), „Pamiętnik Kijowski”, t. 5, Warszawa 1995, s. 52; Dzwonkowski, Kościót katolicki w ZSSR, s. 134.

${ }^{20}$ Zob. „Известия”, Винница, 9 апреля 1922, № 77(435), s. 1.

${ }^{21}$ ДАВО, Р-925, оп. 6, спр. 27, к. 41.

${ }^{22}$ Tamże, к. 17.

${ }^{23}$ Tamże, k. 7.

${ }^{24}$ Tamże, оп. 2, спр. 879, k. 2; спр. 886, к. 3.

${ }^{25}$ Praktycznie od początku kwietnia w centralnej gubernialnej gazecie komitetu wykonawczego i Komunistycznej Partii (bolszewików) Ukrainy na Podolu ukazywały się artykuły dotyczące rekwizycji kosztowności kościelnych. Por. Е. Яковлев, Голод и золото ичерквей, „Известия”, Винница, 4 апреля 1922, № 73 (431), s. 1; tenże, Ценности храмов - в обмен нахлеб, tamże, 9 апреля 1922, № 77 (435), s. 1; Г. Гитаев, Князья церкви и помощь голодающим, tamże, 5 апреля 1922, № 74 (432), s. 1. W ramach kampanii propagandowej podczas konfiskaty kosztowności władze partyjne w Jampolu na Podolu przygotowały nawet specjalną edycję gazety w celu, jak to określiły, „uderzenia po religijnym uczuciom chłopów”. Por. ДАВО, П-8, оп. 1, спр. 50, k. 51.

${ }^{26}$ ДАВО, Р-925, оп. 2, спр. 886, k. 1.

${ }^{27}$ Na przykład w Derażni taki zjazd, na którym zebrało się około 70 osób, odbył się już 9 kwietnia 1922 roku. „Известия”, Винница, 12 апреля 1922, № 79 (437), s. 2. Podobny wiec zorganizowano również w Płoskirowie w miejscowym teatrze, na którym byli obecni przedstawiciele władz wykonawczych, wierni i duchowieństwo różnych wyznań. Zob. ДАВО, П-1, оп. 1, спр. 998, к. 23. W Kamieńcu Podolskim powiatowy komitet wykonawczy zorganizował zaś w miejskim polskim klubie dnia 17 kwietnia specjalną lekcję pt. „O kościelnych kosztownościach”. Zob. B. M. Сторчовий, В. А. Нестеренко, Римсько-Католищька Церква на Поділлі у 20-ті-90-ті роки XX cm. Історико-релігієзнавче дослідження, Коломия 2001, s. 14. Z kolei Jampolski powiatowy 
Gubernialna komisja do spraw rekwizycji kosztowności kościelnych na posiedzeniu z 4 kwietnia 1922 roku ustaliła plan działania. Zgodnie z nim zalecono najpierw przeprowadzić rozmowy z miejscowym duchowieństwem. Faktyczną konfiskatę zamierzano rozpocząc dnia 10 kwietnia najpierw w największych miastach guberni: Winnicy, Kamieńcu Podolskim, Płoskirowie i Mohylowie Podolskim. Prawdopodobnie w obawie przed sprzeciwem ze strony wiernych zaproponowano, aby wydziały administracyjne oraz Gubernialne CzK przygotowały plan ochrony porządku publicznego w poszczególnych powiatach. Na polecenie komisji wzmocniono też skład powiatowych trójek (zaoczny sąd, skazujący w trybie administracyjnym $)^{28}$. Zgodnie z rozporządzeniem WUCWK lokalne władze miały też obowiązek do momentu rozpoczęcia rekwizycji ustanowić tajny nadzór nad najbogatszymi świątyniami w celu zapobiegania kradzieży i ukrycia kosztowności kościelnych ${ }^{29}$.

W samej Winnicy prace rozpoczęto praktycznie w pierwszej dekadzie kwietnia. Gubernialna komisja do spraw konfiskaty kosztowności kościelnych już 8 kwietnia 1922 roku zwróciła się do dziekana i proboszcza winnickiego księdza Jana Lewińskiego z prośbą o podanie terminu dla przeprowadzenia oględzin kościoła. Zastrzeżono też, aby oprócz księdza w tym dniu byli przedstawiciele komitetu kościelnego ${ }^{30}$. W najbliższym tygodniu w Kościele przypadały Święta Wielkanocne, więc proboszcz winnicki podał dwie możliwe daty 11 lub 21 kwietnia $^{31}$. Komisja nie zdecydowała się przystąpić do rekwizycji przed świętami, a GPU ${ }^{32}$ zaproponowało nawet przesunąc termin rozpoczęcia konfiskaty na okres poświąteczny ${ }^{33}$. Nie zważając na to powiatowa komisja w Żmerynce na posiedzeniu z 13 kwietnia 1922 roku postanowiła wezwać do siebie proboszczów parafii w Brahiłowie i w Barze w celu omówienia z nimi sprawy rekwizycji kosztowności kościelnych ${ }^{34}$. Zazwyczaj na takim spotkaniu różnymi sposobami namawiano duchowieństwo, aby wystąpiło z odezwą do wiernych o dobrowolnym oddawaniu kosztowności kościelnych na rzecz głodujących ${ }^{35}$. Władzom udało się nawet prze-

komitet Komunistycznej Partii (bolszewików) Ukrainy planował zwołać ogólne zgromadzenie duchowieństwa i przewodniczących wspólnot religijnych na 30 kwietnia. ДАВО, П-8, оп. 1, спр. 50, к. 49.

${ }^{28}$ ДАВО, Р-925, оп. 6, спр. 27, к. 7-8.

${ }^{29}$ Tamże, к. 16.

${ }^{30}$ Tamże, к. 3.

31 Tamże, к. 38.

${ }^{32}$ Государственное Политическое Управление (Państwowy Zarząd Polityczny) (1922-1934), kontynuacja CzK.

33 ДАВО, Р-925, оп. 2, спр. 878, k. 19.

${ }^{34}$ Tamże, спр. 886, к. 23. W tym czasie parafie te obsługiwali księża Jan Łukacz (Bar) oraz Makary Karoweć OSBM (Brahiłów). Zob. „Wiadomości Diecezjalne Kamienieckie”, 1(1920) nr 7-2(1921) nr 12, s. 4; J. Jaruzelski, Z archiwaliów Ministerstwa Spraw Zagranicznych II Rzeczypospolitej. Po 50 latach kolekcja sovieticów wraca z Waszyngtonu (cz. 3), „Przegląd Wschodni”, 1992-1993, z. 2 (6), s. 442; F. Rzemieniuk, Obraz diecezji kamienieckiej w latach 19181939, „Przegląd Wschodni”, 2002, z. 1 (29), s. 129.

${ }^{35}$ Por. R. Rzewuski, Kapłani pod rzadami ,, sowietów”, „Przegląd Katolicki”, 1922, nr 8, s. 121; Вінницький капуцинський монастир, Вінниця 1995, s. 85. 
konać do poparcia tej kampanii niektórych kapłanów. W tej kwestii „,wzorową postawę", w rozumieniu kierownictwa partyjnego, wśród duchowieństwa rzymskokatolickiego na Podolu przyjął ksiądz Zygmunt Kwaśniewski z Płoskirowa. Wierząc, iż może to uratować niejedną ofiarę głodu, proboszcz płoskirowski na ogólnym zebraniu duchowieństwa z całego powiatu wystąpił z gorącym wezwaniem o wsparcie rządu w dziele pomocy głodującym. Natomiast w czasie konfiskaty, po przekazaniu wszystkich kosztowności kościelnych, ksiądz Kwaśniewski osobiście ofiarował dla głodujących własny złoty medal za osiągnięcia w nauce, różne srebrne monety o wartości numizmatycznej oraz carskie ruble srebrne. Powiatowe władze później nie raz w czasie rekwizycji w innych świątyniach stawiali przykład tego księdza ${ }^{36}$. W rzeczywistości jednak władza nie ufała nikomu. Co ciekawe GPU w specjalnym dodatku do rozporządzenia o konfiskacie kosztowności rekomendowała miejscowej administracji państwowej, aby nie dowierzała zbytnio lojalnym przedstawicielom kręgów religijnych, aby wstrzymywała się też od wspólnego ,kombinowania” i wyjaśnienia z nimi tych czy innych pytań oraz starała się dyktować im swoją wolę ${ }^{37}$.

W tym czasie GubWK ${ }^{38}$ na Podolu na polecenie NKWD zarządził, aby wszystkie powiatowe organy władzy administracyjnej pilnie przeprowadziły weryfikację inwentarzy kościelnych sprzed 1917 roku z faktycznym stanem posiadania świątyń w celu zapobiegania zniknięciu i grabieży kosztowności kościelnych ${ }^{39}$. Dyrektywa ta w szczególny sposób zwracała uwagę na znane z bogactwa cerkwie i kościoły, których mienie nie zostało jeszcze przekazane wiernym na podstawie dekretu o oddzieleniu Kościoła od państwa ${ }^{40}$.

$\mathrm{Na}$ terytorium guberni podolskiej do rekwizycji kosztowności kościelnych przystąpiono faktycznie dopiero po 18 kwietnia 1922 roku. Wtedy dostosowano personalny skład gubernialnej komisji do spraw konfiskaty kosztowności kościelnych do wymogów stawianych przez WUCWK. Na mocy zarządzenia GubWK na Podolu nr 174 z 18 kwietnia powołano nowy skład gubernialnej komisji ${ }^{41}$ pod kierownictwem członka WUCWK i przewodniczącego GubWK oraz gubernialnego komitetu pomocy głodującym W. I. Porajko ${ }^{42}$. Dokument ten również naka-

${ }^{36}$ Por. Державний Архів Хмельницької Області (dalej: ДАХО), Р-6193, оп. 12, спр. П14017, к. 47-48. Pisano nawet o tym w gazetach. Zob. „Известия”, Винница, 5 мая 1922, № 94 (446), s. 3.

37 ДАВО, Р-925, оп. 2, спр. 878, k. 39.

${ }^{38}$ Губерніальний Виконавчий Комітет (Gubernialny Komitet Wykonawczy).

${ }^{39} \mathrm{Na}$ przykład w kościołach katolickich w Kamieńcu Podolskim, które należały do jednych z najbogatszych w diecezji, takie rewizje zostały przeprowadzone już 12 kwietnia 1922 r. Wówczas spisano i obliczono wszelkie rzeczy ze złota i srebra, jak to wota i szaty z obrazów, krzyże itp. Por. Jaruzelski, Z archiwaliów Ministerstwa Spraw Zagranicznych (cz. 2), „Przegląd Wschodni”, 19921993, z. 1 (5), s. 147; APIS, sygn. A. 12. P/6/4/35, k. 192; Kościót katolicki na Ukrainie, s. 48.

40 ДАВО, Р-925, оп. 6, спр. 27, к. 15, 23.

${ }^{41}$ Dokładny skład komisji do spraw konfiskaty kosztowności kościelnych na każdym szczeblu władzy lokalnej i centralnej określało specjalne rozporządzenie WUCWK z 19 kwietnia 1922 roku. Por. ДАВО, Р-925, оп. 2, спр. 878, k. 15-17.

${ }^{42}$ Poza tym do gubernialnej komisji należeli: członkowie prezydium GubWK G. Rakitow i Smirnow, jako zastępcy przewodniczącego oraz przewodniczący GPU Zakowski, kierownik 
zywał powołać podobne komisje w powiatach oraz bezzwłocznie przystąpić do rekwizycji na bazie instrukcji WUCWK oraz dyrektyw gubernialnej komisji. Całą pracę należało zakończyć nie później niż 5 maja 1922 roku $^{43}$. W dniu 18 kwietnia w Winnicy skompletowano również odrębne komisje dla poszczególnych wy$z n^{44}$. Podobnie sytuacja wyglądała i w innych większych miastach na Podolu. W przeddzień rozpoczęcia rekwizycji kosztowności kościelnych w Winnicy rada miejska oświadczyła, iż konfiskatę należy przeprowadzać w sposób „nieugięty, twardy i energiczny", a każdy sprzeciw zdecydowanie karać i winnych oddawać pod sąd ${ }^{45}$. Uchwała ta znalazła też swój wyraz w ściśle tajnej Instrukcji nr 990 z 21 kwietnia 1922 roku opracowanej przez organa GPU i skierowanej do osób odpowiedzialnych za konfiskatę w powiatach i gminach. Zaznaczała ona, że winnych w ukrywaniu kosztowności kościelnych należy niezwłocznie oddawać pod sąd Rewtrybunału ${ }^{46}$; rekwizycję przeprowadzać w miarę możliwości niespodziewanie, w celu uniknięcia niepotrzebnych ekscesów, a osoby prowadzące agitację aresztować i wysyłać do gubernialnej CzK; o wszystkich incydentach, plotkach i nastrojach wśród duchowieństwa i wiernych donosić każde 48 godzin $^{47}$. Na mocy powyższych rozporządzeń na Podolu we wszystkich powiatach zdołano do 25 kwietnia rozpocząć pracę, która trwała praktycznie do końca maja ${ }^{48}$.

Największym problemem dla prac komisji rekwirujących kosztowności kościelne na Podolu okazał się brak w wielu parafiach, szczególnie w powiecie winnickim i kamienieckim, spisów inwentarzowych sprzed 1917 roku $^{49}$. Często były one celowo ukrywane przed komisją, aby nie dopuścić do ograbienia świątyni. Z kolei inwentarze sporządzone już za rządów bolszewickich w latach 1921-1922 centralne organy władzy w Charkowie nie akceptowały ${ }^{50}$. To właśnie stało się przyczyną wszczęcia sprawy przeciwko księdzu J. Lewińskiemu z Winnicy. Konfiskata kosztowności w kościele winnickim została przeprowadzona w dniu 21 kwietnia 1922 roku $^{51}$. Pomimo braku starych inwentarzy komisja nie zaprzestała pracy i zarekwirowała wówczas wszystkie znalezione wartościowe przedmioty ze złota, srebra i kamieni szlachetnych. Między innymi zabrano 80 srebrnych wotów, 16 srebrnych świeczników, dwie srebrne ampułki oraz złoty pierścień z kamieniami, którego wartość oceniono na 525 tysięcy rubli ${ }^{52}$. W przeliczeniu na

wydziału finansowego Kalinkin, komisarz wojskowy Dzyza i kierownik wydziału prawnego Jakowlew, jako członkowie. Zob. ДАВО, Р-925, оп. 2, спр. 878, k. 40.

${ }^{43}$ ДАВО, Р-925, оп. 2, спр. 584, k. 26.

${ }^{44} \mathrm{~W}$ skład komisji rekwirującej kosztowności w kościele katolickim w Winnicy weszli: przedstawiciel gubernialnej komisji tow. Kalinkin, jako przewodniczący oraz dwóch członków Jagodziński i Radecki. Por. Tamże, k. 28.

${ }^{45}$ „Известия”, Винница, 21 апреля 1922, № 83 (441), s. 2.

${ }^{46}$ Rewolucyjny Trybunał.

${ }^{47}$ Por. ДАВО, Р-925, оп. 2, спр. 886, k. 27; Вінницький капуцинський монастир, s. 85.

48 ДАВО, Р-925, оп. 2, спр. 879, k. 2; спр. 886, к. 3.

49 „Известия”, Винница, 5 мая 1922, № 94 (452), s. 3.

${ }^{50}$ ДАВО, Р-835, оп. 1, спр. 354, k. 86.

51 „Известия”, Винница, 25 апреля 1922, № 86 (444), s. 1.

52 „Известия”, Винница, 26 апреля 1922, № 87 (445), s. 2. 
współczesną miarę wagi było to ponad $7 \mathrm{~kg}$ srebra $^{53}$. Z powodu braku starych spisów inwentarzowych sporządzono osobny protokół, a sprawę skierowano do Gubrewtrybunału ${ }^{54}$. Na polecenie komisji gubernialnej z dnia 26 kwietnia 1922 roku rozpoczęto postępowanie w sprawie kościoła w Winnicy ${ }^{55}$. Śledczy Podolskiego Gubrewtrybunału już 12 maja przesłuchał oskarżanego o ukrywanie kosztowności kościelnych księdza Lewińskiego wraz kilkoma przedstawicielami parafii ${ }^{56}$. Proboszcz winnicki tłumaczył wówczas, że wspomniane inwentarze prawdopodobnie zaginęły w czasie zawieruchy wojennej, a nowe zostały sporządzone na początku 1921 roku, gdy podpisywano umowę dzierżawczą z komisją likwidacyjną ${ }^{57}$. Księdzu Janowi nie uwierzono, wkrótce aresztowano go i oddano pod sąd ${ }^{58}$. Rozprawa sądowa odbyła się w Winnicy na początku czerwca 1922 roku. Wraz z księdzem Lewińskim na ławie oskarżonych zasiedli też dwaj duchowni prawosławni. Przebieg tego procesu głośno opisywała miejscowa prasa. ${ }^{59}$ Autor jednego z artykułów tak scharakteryzował proboszcza w Winnicy: „wysoki, krzepki mężczyzna, zachowuje się z godnością. Na pytania sądu odpowiada dokładnie, sensownie i poprawnie" 60 . Po całodziennym przesłuchaniu 5 czerwca 1922 roku zapadł ostateczny wyrok. Ksiądz Lewiński został skazany na 4 miesiące przymusowych prac, z zamianą na grzywnę w wysokości 300 milionów rubli na pomoc dla głodujących, którą musiał wnieść w ciągu 72 godzin ${ }^{61}$.

W tym samym czasie pod śledztwem za ukrywanie kosztowności kościelnych znaleźli się i inni kapłani diecezji kamienieckiej: Jan Łukacz ${ }^{62}$ z Baru (dekanat

${ }^{53}$ Obdarto też z szat obraz NMP, znajdujący się w głównym ołtarzu. Вінницький капуциннський монастир, s. 87-88. Według innych źródeł w Winnicy skonfiskowano ogółem 29 funtów srebra (ok. $11,8 \mathrm{~kg}$ ) oraz 3 zołotniki złota (12,8 g). Ks. T. M., Z „raju” bolszewickiego, „Przegląd Katolicki”, 1922, nr 9, s. 131.

${ }^{54}$ ДАВО, Р-925, оп. 2, спр. 879, к. 3; спр. 886, к. 1.

55 Tamże, спр. 887, к. 2.

${ }^{56}$ Oprócz organisty Mikołaja Szarkiewicza, byli to przedstawiciele komitetu kościelnego: przewodniczący Stanisław Zieliński, sekretarz Edmund Wychowski oraz Łukasz Jadłowski. Por. „3 архівів ВУЧК-ГПУ-НКВД-КГБ”, 2003, № 2 (21), dok. 17, s. 67-70; ․ Rubliowa, Represje władz Ukrainy Radzieckiej wobec duchowieństwa rzymskokatolickiego w okresie międzywojennym. Nowe dokumenty, „Przegląd Wschodni”, 2004, z. 2 (34), s. 446-448.

${ }^{57}$ Rubliowa, Represje władz Ukrainy Radzieckiej, s. 447; „3 архівів ВУЧК-ГПУ-НКВД-КГБ”, 2003, № 2 (21), dok. 17, s. 68.

${ }^{58}$ Jaruzelski, Z archiwaliów Ministerstwa Spraw Zagranicznych (cz. 2), s. 154.

${ }^{59}$ Zob. Завтра дело Винницких попов, „Известия”, Винница, 2 июня 1922, № 117 (475) s. 3; Е. Яковлев, Суд над Винницикими , князьями”, tamże, 3 июня 1922, № 118 (476) s. 1, 3; Л. Дарин, Суд над Винницкими управителями ценностей, tamże, 5 июня 1922, № 120 (478) s. 3.

${ }^{60}$ Дарин, Суд над Винниџкими управителями ценностей, s. 3; Вінниџький капуиинський монастир, s. 86.

${ }^{61}$ „Известия”, Винница, 5 июня 1922, № 120 (478) s. 3; ДАВО, Р-925, оп. 2; спр. 886, к. 72; P-196, оп. 1, спр. 104, к. 47; Archiwum Akt Nowych (dalej: AAN), Ambasada RP w Londynie (dalej: APL), sygn. 887, k. 21; „Gazeta Kościelna”, 1923, nr 1, s. 7; „3 архівів ВУЧК-ГПУ-НКВДКГБ”, 2003, nr 2 (21) dok. 20, s. 72, 408; Вінницький капуцинський монастир, s. 87.

${ }^{62}$ ДАХО, Р-6193, оп. 12, спр. П-22068, к. 1, 13. Był on dwukrotnie aresztowany. Pierwszy raz jeszcze na przełomie maja-czerwca za stawianie oporu rekwizycji kosztowności kościelnych. 
mohylowski), Emanuel Kapłonowski ${ }^{63}$ obsługujący parafie Stara i Nowa Uszyca, Struga i Zamiechów (dekanat uszycki) oraz Wiktor Stronczyński ${ }^{64}$ z Murafy (dekanat jampolski). W jednym ze sprawozdań o przebiegu kampanii rekwizycji kosztowności na Podolu informowano też, iż w powiecie mohylowskim za przeciwstawienie się konfiskacie do odpowiedzialności pociągnięto czterech księży katolickich $^{65}$.

Dla szybszego rozpatrywania spraw związanych z konfiskatą kosztowności kościelnych na terytorium całej guberni została wydelegowana nawet specjalna wyjazdowa sesja Gubrewtrybunału, która z dniem 5 maja miała przystąpić do pracy $^{66}$. Tabela nr 1 przedstawia liczbę rozpatrywanych przez niego spraw w ciągu maja-czerwca 1922 roku w poszczególnych powiatach na Podolu. Najczęściej koncentrowano się wokół trzech zarzutów: ukrywanie kosztowności kościelnych, przeciwstawianie się konfiskacie oraz odmowę wydania inwentarzy.

Tabela 1. Liczba spraw przekazanych do sądu wyjazdowej sesji Rewtrybunału według stanu na 30 czerwca 1922 roku

\begin{tabular}{|l|c|c|}
\hline \multicolumn{1}{|c|}{ Powiat } & Ilość spraw & W tym dotycząca katolików \\
\hline Winnicki & 13 & 1 \\
\hline Mohylowski & 8 & 4 \\
\hline Hajsyński & 16 & $(-)$ \\
\hline Żmeryniecki & 1 & 1 \\
\hline Uszycki & 6 & 2 \\
\hline Płoskirowski & 17 & $(-)$ \\
\hline Kamieniecki & 25 & 4 (co najmniej) \\
\hline \multicolumn{1}{|c|}{ Suma } & 86 & 12 \\
\hline
\end{tabular}

Źródło: ДАВО, Р-925, оп. 2, спр. 879, k. 17; спр. 886, к. 2, 46, 72.

Aresztowano wówczas też dwóch kapłanów prawosławnych i kilku członków komitetu cerkiewnego za ukrywanie kosztowności w klasztorze barskim. Zob. ДАВО, Р-925, оп. 2, спр. 879, k. 17. Drugi - w lipcu lub sierpniu 1922 roku, ze względu na sprawę miejscowego organisty, który przechowywał niektóre kosztowności. Biblioteka KUL, Rkp. 2343, M. Sokołowski, Jeszcze jedna karta z życia kresowego kapłana, Wrocław 1982-1986, mps, k. 126; Jaruzelski, Z archiwaliów Ministerstwa Spraw Zagranicznych (cz. 2), s. 158; APIS, sygn. A. 12. P/6/4/35, k. 197; Kościół katolicki na Ukrainie, s. 53. Z akt sprawy księdza Łukacza wynika, że śledztwo to zostało w końcu umorzone.

${ }^{63}$ Po miesiącu przebywania $\mathrm{w}$ areszcie został zwolniony $\mathrm{z}$ braku dowodów winy. ДАХО, Р-6193, оп. 12, спр. П-11518, k. 19, 64; Ks. Т. М., Z „,raju” bolszewickiego, „Przegląd Katolicki”, 1922, nr 9, s. 132.

${ }^{64}$ Kapłan ten był dwukrotnie sądzony za ukrywanie i przywłaszczenie kosztowności kościelnych. Za drugim razem był nawet warunkowo skazany na 2 lata. Zob. ДАВО, Р-6023, оп. 4, спр. 25483, k. 26, 40. Powodem tego, jak uważa A. Lysyj, był fakt, że w kościele w Murafie władza w 1922 roku nie znalazła żadnych kosztowności. А. Лисий, Нариси історії Мурафського костьолу Непорочного Зачаття Діви Марії (1625-2000), Вінниця 2000, s. 51.

${ }^{65}$ ДАВО, Р-925, оп. 2, спр. 879, k. 17. Było to jednak mało prawodopodobne. Na terytorium ówczesnego powiatu mohylowskiego istniało 6 kościołów, obsługiwanych tylko przez trzech kapłanów. Nie ma też żadnych innych potwierdzeń źródłowych, że ci księża ponosili jakieś kary w związku z konfiskatą.

${ }^{66}$ Kierował nią przewodniczący rewolucyjnego trybunału 24 dyw. Porukow, a w skład weszli 
W obronie rabowanych i nieraz profanowanych świątyń na Podolu stawali także sami wierni. Między innymi znane są wypadki krwawego stłumienia podobnych sprzeciwów katolickiej ludności w Gródku Podolskim (dekanat kamieniecki) ${ }^{67}$ oraz Czerniowcach (dekanat jampolski) ${ }^{68}$. Pod sąd Gubrewtrybunału trafiły też dwa kościelne komitety parafialne w powiecie uszyckim ${ }^{69}$. Niektóre z świątyń, jak na przykład kościół w Jampolu, były kilkakrotnie okradane z cennych rzeczy już w ciągu 1921 roku $^{70}$. W kościele w Derażni też dwukrotnie przeprowadzano rekwizycję kosztowności ${ }^{71}$ a $\mathrm{w}$ czasie jednej z nich wyciągnięto nawet puszkę z Najświętszym Sakramentem i badano ją czy nie jest ze srebra ${ }^{72}$.

Największy rozgłos na całym Podolu miały jednak wydarzenia w Kamieńcu Podolskim, gdzie opór wiernych i duchowieństwa rzymskokatolickiego przeciwko rekwizycjom przyjął najbardziej dramatyczną formę. Według zeznań jednego ze świadków, księża kamienieccy, gdy dowiedzieli się o zamiarach władz, postanowili na wspólnej naradzie nie oddawać kosztowności kościelnych i ukryć je u najbardziej zaufanych katolików, oznajmiając, że wszystko wywiózł ze sobą do Polski biskup Piotr Mańkowski ${ }^{73}$.

Katolicka ludność Kamieńca, na wieść o konfiskacie kosztowności kościelnych, już 18 kwietnia 1922 roku thumnie (ok. 600 osób) zebrała się wokół katedry w celu nie dopuszczenia do rabunku kościołów w tym mieście i przez całą noc pilnowała swoich świątyń. W następnym dniu, gdy zjawiła się komisja do spraw rekwizycji kosztowności kościelnych w składzie: naczelnik CzK w Kamień$\mathrm{cu}$ - Bredis, kierownik tajnego wydziału operacyjnego - Twerdochlebow oraz kierownik gospodarstwa komunalnego - Szenajzen, katolicy odmówili wydania kluczy i siłą wyrzucili komisję. W tej sytuacji przewodniczący powiatowego komitetu wykonawczego P. Bucenko zwołał nadzwyczajne posiedzenie, na którym postanowiono natychmiast rozpędzić tłum i wykonać postanowienie o rekwizycji kosztowności kościelnych. Przy pomocy konnego oddziału czekistów i milicji, które nie zawahały się użycia broni palnej i nahajek, władzy udało się rozpędzić zebraną ludność katolicką. Wówczas został aresztowany proboszcz katedry

członek kolegium Charitonow oraz w zależności od miejsca pracy sesji przewodniczący powiatowego komitetu wykonawczego. Zob. ДАВО, Р-207, оп. 5, спр. 1, к. 25, 35.

${ }^{67}$ Donoszono wówczas ordynariuszowi kamienieckiemu do Polski, że w wyniku wywiązania się strzelaniny do tłumu w trakcie rekwizycji kosztowności kościelnych zginęło w Gródku 3 osoby oraz 14 było rannych. Bp Mańkowski do bpa Szelażka, Buczacz, 27 kwietnia 1922, Archiwum Archidiecezjalne w Gnieźnie (dalej: AAG), Archiwum Prymasa Polski (dalej: APP), I/144c, k. 2.

${ }^{68}$ APIS, sygn. A. 12. P/6/4/35, k. 196; Kościót katolicki na Ukrainie, s. 52; Jaruzelski, Z archiwaliów Ministerstwa Spraw Zagranicznych (cz. 2), s. 151-152; AAN APL, sygn. 887, k. 7.

${ }^{69}$ ДАВО, Р-925, оп. 2, спр. 886, k. 46.

${ }^{70}$ Por. APIS, sygn. A. 12. P/6/4/35, k. 196; Kościót katolicki na Ukrainie, s. 52; Jaruzelski, $Z$ archiwaliów Ministerstwa Spraw Zagranicznych (cz. 2), s. 151; AAN, APL, sygn. 887, k. 6. W czasie jednego z rabunków w październiku 1921 roku został nawet aresztowany proboszcz jampolski ks. Józef Berezowski. Zob. ДАВО, Р-6023, оп. 4, спр. 4603, к. 164.

${ }^{71}$ APIS, sygn. A. 12. P/6/4/35, k. 197; Kościót katolicki na Ukrainie, s. 53.

${ }^{72}$ Ks. T. M., Z „,raju” bolszewickiego, „Przegląd Katolicki”, 1922, nr 9, s. 131.

${ }^{73}$ Por. ДАХО, Р-6193, оп. 12, спр. П-19263, к. 48; Сторчовий, Нестеренко, Римсько-католииька Церква на Поділлі, s. 14. 
ksiądz Antoni Niedzielski ${ }^{74}$ oraz wielu innych Polaków, stawiających opór przy konfiskacie. ${ }^{75}$

W Kamieńcu, jak informowały raporty GPU, aresztowano i wszczęto śledztwo przeciwko 7 podżegaczom i kilku obywatelom wyznania katolickiego z powodu utrudniania konfiskaty kosztowności oraz pobicia członków komisji ${ }^{76}$. Gdy do Charkowa nadeszły wieści o aktywnym wystąpieniu przeciwko rekwizycjom polskiego duchowieństwa rzymskokatolickiego w Kamieńcu ${ }^{77}$, już pod koniec kwietnia kategorycznie zarządzono, aby miejscowe władze wykonawcze przedsięwzięły odpowiednie środki szybkiej i surowej kary, a same wystąpienia wykorzystały w celach propagandowych ${ }^{78}$.

Komisja kamieniecka ponownie zjawiła się w katedrze 20 kwietnia i pod groźbą rozstrzelania wszystkich aresztowanych ${ }^{79}$ zażądała wpuszczenia jej do świątyni. Dopiero pod tą presją parafianie ustąpili i przekazali klucze, poczym władza od razu przystąpiła do rekwizycji ${ }^{80}$. Wówczas tylko z samej katedry skonfiskowano wiele różnych srebrnych rzeczy, m.in. kielichy, monstrancję oraz obraz Matki Bożej w srebrnej szacie ${ }^{81}$. Księdzu Niedzielskiemu po zwolnieniu z aresztu wierni zaproponowali ucieczkę do Polski, jednak on odmówił ze względu na pozostającą tu najbliższą rodzinę ${ }^{82}$. Nie zważając na sprzeciw katolickiego duchowieństwa i wiernych w Kamieńcu władzom udało się na przełomie kwietnia - maja skonfiskować sporą część kosztowności kościelnych. W tym czasie, jak podawała prasa, zdołano zarekwirować tylko w samym Kamieńcu z czterech kościołów 50 różnych przedmiotów wartościowych i złomu srebrnego o wadze ponad 1,5 puda

${ }^{74}$ Bezpośrednio po tym przeprowadzono dokładną rewizję w jego mieszkaniu, zerwano podłogę, powalono piece i ściany, szukając ukrytych kosztowności. Zob. Jaruzelski, Z archiwaliów Ministerstwa Spraw Zagranicznych (cz. 2), s. 145-146.

${ }^{75}$ Wśród aresztowanych znaleźli się miedzy innymi Antoni Gips, Wirek, Korowicki, Komarnicki, Dzikowski. APIS, sygn. A. 12. P/6/4/35, k. 192-193; Kościót katolicki na Ukrainie, s. 49; Jaruzelski, Z archiwaliów Ministerstwa Spraw Zagranicznych (2), s. 145-147; Dzwonkowski, Kościót katolicki w ZSSR, s. 136-137; Сторчовий, Нестеренко, Римсько-католицька Церква на Поділлі, s. 14-15.

${ }^{76}$ ДАВО, Р-925, оп. 2, спр. 879, к. 3; спр. 886, k. 1.

${ }_{77}$ Tamże, спр. 879, k. 2; спр. 886, к. 3.

${ }^{78}$ Tamże, спр. 878, к. 18.

${ }^{79}$ Wśród zakładników znaleźli się ks. Niedzielski i wierni: Kuk, Gips, Laskowska, Niepokójczycka oraz Kilczyńska. Por. APIS, sygn. A. 12. P/6/4/35, k. 193; Kościół katolicki na Ukrainie, s. 49.

${ }^{80}$ Jaruzelski, Z archiwaliów Ministerstwa Spraw Zagranicznych (cz. 2), s. 149.

${ }^{81}$ Bp Mańkowski do bpa Szelą̇ka, Buczacz, 27 kwietnia 1922, AAG, APP, I/144c, k. 2.

${ }^{82}$ ДАХО, Р-6193, оп. 12, спр. П-19263, к. 48; Сторчовий, Нестеренко, Римсько-католицька Церква на Поділлі, s. 16. 
(około $25 \mathrm{~kg})^{83}$. Podobne konfiskaty dotknęły również kościoły katolickie w całym powiecie kamienieckim ${ }^{84}$.

W tej sytuacji katolicy kamienieccy wysłali nawet petycję do władz w Charkowie, zaopatrzoną w około 700 podpisów, z prośbą o możliwość zamiany kosztowności kościelnych na odpowiednią sumę pieniędzy lub produkty żywnościowe dla głodujących ${ }^{85}$. Akcja ta jednak pozostała bez skutku. Gubernialna komisja już 26 kwietnia wydała rozporządzenie, aby nie pozwalać wiernym na żadne zamiany kosztowności kościelnych ${ }^{86}$. Centralna komisja w Charkowie pismem okólnym z dnia 27 kwietnia 1922 roku wyjaśniła, że kosztowności kościelne pod żadnym pozorem nie mogą pozostawać w świątyniach, a możliwości pertraktacji o ich zamianie należy prowadzić tylko po uprzednim przedstawieniu przez wspólnotę ekwiwalentu w złocie i srebrze, zaś kosztowności o znaczeniu muzealnym wcale nie podlegają wymianie ${ }^{87}$. Ostateczną decyzję w tej kwestii faktycznie wydawały miejscowe władze wykonawcze. Kamieniecka komisja do spraw rekwizycji kosztowności kościelnych na posiedzeniu z 4 maja 1922 roku pozwoliła na zamianę jedynie w katedrze prawosławnej oraz w wielkiej synagodze, zaś pozostałym, w tym katolikom odmówiono ${ }^{88}$.

W obawie przed powtórzeniem się sytuacji z Kamieńca Podolskiego w powiecie jampolskim komisja do spraw rekwizycji kosztowności kościelnych wolała już zabezpieczyć się od niepożądanych ekscesów. Dlatego na pierwszym posiedzeniu z 26 kwietnia postanowiono przede wszystkim zmobilizować wszystkie partyjne komórki oraz prosić naczelnika jampolskiego wojskowego okręgu na czas konfiskaty utrzymywać w pogotowiu na wszelki wypadek wojsko ${ }^{89}$. W powiecie tym praktycznie cała kampania minęła bez większych zakłóceń, jedynie w Tomaszpolu, jak donosił jeden z raportów, ksiądz katolicki i kilka miejscowych popów próbowali bezskutecznie sprowokować komisję ${ }^{90}$.

Tabela nr 2 przedstawia ilość zarekwirowanych kosztowności na rzecz pomocy głodującym w kościołach powiatu jampolskiego. Na tym obszarze było w sumie 5 parafii katolickich, z których tylko w Murafie komisja do spraw konfiskaty nie znalazła żadnych cennych rzeczy ${ }^{91}$. Niektóre kościoły na Podolu były tak

${ }^{83}$ Ks. T. M., Z ,raju” bolszewickiego, „Przegląd Katolicki”, 1922, nr 9, s. 131. Między innymi z katedry rekwirowano 31 kosztownych przedmiotów i różnego srebra wagą ok. 10,6 kg, trynitarskiego -8 przedmiotów (ok. 2,6 kg), ormiańskiego - 10 przedmiotów i srebrny łom (ok. 10,6 $\mathrm{kg}$ ) oraz dominikański - 1 przedmiot (ok. 1,3 kg). Сторчовий, Нестеренко, Римсько-католицька Церква на Поділлі, s. 15.

${ }^{84} \mathrm{Na}$ przykład w kościele żwanieckim zabrano 3 cenne przedmioty, srebrne monety i znaczna ilość waluty polskiej i austriackiej; w Zieńkowcach - kilkadziesiąt różnych srebrnych rzeczy, jak to wotywa, krzyży, ikony itd.; w Smotryczu dużą ilość srebra. Por. Сторчовий, Нестеренко, Римськокатолицька Церква на Поділлі, s. 15.

${ }^{85}$ Zob. Bp Mańkowski do bpa Szelążka, Buczacz, 27 kwietnia 1922, AAG, APP, I/144c, k. 2.

${ }^{86}$ ДАВО, Р-925, оп. 2, спр. 887, к. 2.

${ }^{87}$ Tamże, спр. 878, k. 38.

${ }^{88}$ ДАХО, Р-336, оп. 1, спр. 37, к. 3.

89 ДАВО, Р-835, оп. 1, спр. 191, k. 1.

90 ДАВО, Р-925, оп. 2, спр. 592, к. 209.

${ }^{91}$ Zob. Лисий, Нариси історії Мурафського костьолу, s. 51. 
ubogie, że nie było w nich co konfiskować ${ }^{92}$. W Tomaszpolu katolikom udało się jednak wykupić srebrny kielich częściowo ze składek, a częściowo za różne srebrne rzeczy. Nie wszędzie jednak miejscowe władze szły na rękę wiernym. Tak na przykład w powiecie olhopolskim zarządzono, aby zabrać wszystkie bez wyjątku cenne rzeczy ze świątyń ${ }^{93}$. Z kościoła w Czeczelniku zabrano nawet rzeczy, które pozostawiono po pierwszej rekwizycji, w tym pozłacany srebrny kielich z pateną, puszkę oraz małe srebrne ikony Najświętszego Serca Jezusa i Matki Bożej. Nie pomogły nawet podania i prośby komitetu parafialnego o zwrot jedynej puszki ${ }^{94}$.

Tabela2. Liczbaskonfiskowanychsrebrnych kosztownościzkościołów wpowieciejampolskim w maju 1922 r.

\begin{tabular}{|l|l|c|c|c|c|c|}
\hline \multicolumn{1}{|c|}{ Kościoły } & \multicolumn{1}{|c|}{ Kosztowności } & Data & Funt & Zołotnik & Dola & Kg \\
\hline \multirow{2}{*}{ Tomaszpol } & Wotywa x 48; lichtarze x 2 & 5 V 1922 & 4 & 72 & & 1,945 \\
\cline { 2 - 7 } & W zamian kielicha (srebro) & 8 V 1922 & 3 & & 84 & 1,232 \\
\hline \multirow{2}{*}{ Dzygówka } & Różne rzeczy & 8 V 1922 & 14 & 57 & 57 & 5,979 \\
\hline \multirow{2}{*}{ Jampol } & Kielich & 11 V 1922 & 1 & 1 & 84 & 0,417 \\
\cline { 2 - 7 } & Patena & - & & 15 & 84 & 0,067 \\
\hline Czerniowce & Różne rzeczy & 12 V 1922 & 1 & 57 & 60 & 0,655 \\
\hline \multicolumn{2}{|c|}{ Suma } & $\mathbf{2 5}$ & $\mathbf{1 3}$ & $\mathbf{8 4}$ & $\mathbf{1 0 , 2 9 5}$ \\
\hline
\end{tabular}

Źródło: ДАВО, Р-835, оп. 1, спр. 195, к. 23; спр. 354, к. 86, 140-141, 157, 167, 191, 208.

O wydarzeniach na Podolu niezwłocznie informowano też ordynariusza kamienieckiego w Buczaczu ${ }^{95}$, który już 20 kwietnia telegrafował o tym do ministra K. Skirmunta przebywającego na konferencji w Genui ${ }^{96}$. Bp Mańkowski o zajściach na Podolu pisał też do pracującego w Ministerstwie Wyznań Religijnych i Oświecenia Publicznego biskupa Adolfa Szelążka ${ }^{97}$, w nadziei, że odpowiednie władze polskie wystosują protest przeciwko tym działaniom władz bolszewickich. Podejmowane próby interwencji Poselstwa Polskiego w Charkowie w tej sprawie, które w głównej mierze były oparte na artykule VII traktatu ryskiego z 1921 ro$\mathrm{ku}$, były jednak ciągle uchylane przez stronę radziecką jako bezpodstawne i nie

${ }^{92}$ Przykładowo w kościele filialnym w Berszadzie (dekanat bałcki) skonfiskowano na fundusz pomocy głodującym jedynie pozłacaną patenę ze srebra wagą niespełna 200 gramów. Zob. ДАВO, P-587, оп. 1, спр. 81, к. 109, 122. Z kolei w kościele dunajowieckim (dekanat uszycki), jak zeznawał proboszcz ks. Antoni Matuszewicz, nie było co zabierać. Por. ДАХО, Р-6193, оп. 12, спр. П-19263, к. 28.

${ }^{93}$ Por. ДАВО, Р-587, оп. 1, спр. 81, k. 161.

${ }^{94}$ Tamże, k. 160.

${ }^{95} \mathrm{Z}$ całej diecezji napływały do niego wiadomości o rabunku kościołów na Podolu, jednak biskup niewiele mógł uczynić w tej sprawie. Zob. Jaruzelski, $Z$ archiwaliów Ministerstwa Spraw Zagranicznych (cz. 2), s. 145.

${ }^{96}$ Zob. Bp Mańkowski do bpa Szelążka, Buczacz, 27 kwietnia 1922, AAG, APP, I/144c, k. 2; P. Mańkowski, Pamiętniki, Warszawa 2002, s. 352.

${ }^{97}$ Bp Mańkowski do bpa Szelą̇ka, Buczacz, 27 kwietnia 1922, AAG, APP, I/144c, k. 2. 
dawały żadnych pozytywnych rezultatów ${ }^{98}$. Podobnie też odrzucano sprzeciwy samych katolików na Ukrainie, tłumacząc, że zgodnie z prawem ukraińskim całe mienie kościelne jest własnością państwa ${ }^{99}$. Biskup ordynariusz, kiedy dowiedział się o aresztowaniach swoich księży w Kamieńcu, pisał ze smutkiem do łacińskiego metropolity lwowskiego arcybiskupa Józefa Bilczewskiego, że trudno na to cokolwiek poradzić, gdyż ,takie u nich wewnętrzne ustawodawstwo, na które i delegacja ryska i Sejm polski jednogłośnie niemal się zgodzili"100.

W Kamieńcu Podolskim i innych miejscowościach na Podolu jednak rekwizycje trwały nadal. Centralne władze wykonawcze w Charkowie już 2 maja 1922 roku zarządziły ponownie dokładnie sprawdzić stan przedwojennych inwentarzy kościelnych we wszystkich religijnych organizacjach. W każdym wypadku jakiegokolwiek braku należało sporządzać akt i winnych oddawać pod sąd trybunału rewolucyjnego. Na tej podstawie zalecano drugi raz sprawdzić, czy wszystko zostało skonfiskowane w świątyniach ${ }^{101}$. Kamieniecka komisja do spraw konfiskaty kosztowności kościelnych 10 maja ponownie zażądała od księży wydania starych inwentarzy. Gdy okazało się, że duchowieństwo rzymskokatolickie ukrywa te spisy wszczęto śledztwo i aresztowano wszystkich kapłanów w Kamieńcu. Zobowiązano ich, że do momentu rozpoczęcia procesu sądowego nie opuszczą miasta. ${ }^{102}$

Z początkiem sierpnia w kamienieckich kościołach zarządzono kolejną rekwizycję kosztowności, bowiem w wyniku postępowania sądowego udało się ustalić, że księża ukryli znaczne ilości kosztowności kościelnych. Rozpoczęto na nowo dokładną penetracje ${ }^{103}$ każdej świątyni oraz aresztowania duchowieństwa i wiernych. Wszystkie kościoły w Kamieńcu zostały zamknięte na ten czas. W wyniku tych działań ze skarbca katedry kamienieckiej zrabowano jeszcze dwie złote monstrancje, złoty krzyż z 3 brylantami po 6 karat ważący ok. 2,7 kg, srebrna statua wieży częstochowskiej, dwa lichtarze srebrne oraz pałasz Wołodyjowskiego ze złotą rękojeścią ${ }^{104}$. W innych kościołach kamienieckich odnaleziono również duże

${ }^{98}$ Por. AAN, APL, sygn. 887, k. 21, 25.

${ }^{99}$ Aby uniknąć nieporozumień na miejscach władze centralne w Charkowie wyjaśniły, że traktat ryski nie jest żadną podstawą prawną do sprzeciwiania się konfiskacie kosztowności kościelnych. Zob. ДАВО, Р-925, оп. 2, спр. 878, k. 12-13.

${ }^{100}$ Por. J. Wołczański, List biskupa Piotra Mańkowskiego do arcybiskupa Józefa Wilczewskiego z lat 1912-1922, w: Pasterz i Twierdza. Księga jubileuszowa dedykowana Księdzu Biskupowi Janowi Olszańskiemu ordynariuszowi diecezji w Kamieńcu Podolskim, red. J. Wołczański, KrakówKamieniec Podolski 2001, list nr 27, s. 439-440.

${ }^{101}$ ДАВО, Р-113, оп. 3, спр. 29, k. 8.

102 Por. Jaruzelski, Z archiwaliów Ministerstwa Spraw Zagranicznych (cz. 2), s. 154; APIS, sygn. A. 12. P/6/4/35, k. 193; Kościót katolicki na Ukrainie, s. 49.

${ }^{103} \mathrm{~W}$ kościołach kamienieckich praktycznie przez cały sierpień, jak donosił jeden z raportów, szukano ukrytych kosztowności po różnych kryjówkach i lochach. Zob. Jaruzelski, $Z$ archiwaliów Ministerstwa Spraw Zagranicznych (cz. 2), s. 158.

${ }^{104}$ Por. APIS, sygn. A. 12. P/6/4/35, k. 193; Kościót katolicki na Ukrainie, s. 49. Poza tym skonfiskowano różnych srebrnych przedmiotów wagą na około 16,4 kg. Сторчовий, Нестеренко, Римсько-католицька Церква на Поділлі, s. 16. 
ilości schowanych kosztowności kościelnych ${ }^{105}$. Znaczna część tych rzeczy trafiła później jako złom w ręce miejscowych handlarzy żydowskich ${ }^{106}$.

Tym razem pod sąd rewolucyjnego trybunału trafili wszyscy czterej księża pracujący w Kamieńcu Podolskim pod zarzutem ukrywania kosztowności kościelnych. Wraz z nimi na ławie oskarżonych zasiadło kilkoro parafian, między innymi siostry Rogozińskie oraz panowie A. Paluszek z matką, A. Gips i Komarnicki. Po kilkutygodniowym śledztwie ostateczny wyrok wyjazdowej sesji Rewtrybunału zapadł 2 września 1922 roku. Księża ${ }^{107}$ Antoni Niedzielski, Ryszard Bohusz-Szyszko, Władysław Dworzecki i Walery Szymański oraz wspomniani wyżej wierni z wyjątkiem Komarnickiego zostali skazani na karę śmierci ${ }^{108}$. Nieco później ze względu na wiek i stan zdrowia została złagodzona kara dla księdza Szymańskiego oraz sióstr Rogozińskich, którzy wkrótce wyszli nawet na wolność, a panu Paluszkowi zamieniono karę śmierci na pięć lat więzienia ${ }^{109}$. Pozostałym zaś początkowo wstrzymano wykonanie wyroku ze względu na interwencję polskich przedstawicielstw dyplomatycznych ${ }^{110}$. Bezpośrednio po zapadnięciu wyroku wystosowano też apelację do Charkowa o ułaskawienie księży ${ }^{111}$. Kierownictwo partyjne guberni podolskiej ze swej strony zabiegało u przewodniczącego WUCWK G. I. Piotrowskiego i przewodniczącego Najwyższego Trybunału S. Buzdalina o utrzymanie w mocy ,sprawiedliwego i ważnego pod względem politycznym" wyroku i odmowie w prośbie o ułaskawienie księży kamienieckich ${ }^{112}$.

${ }^{105} \mathrm{~W}$ kościele dominikańskim za drugim razem skonfiskowano $8,2 \mathrm{~kg}$ różnych srebrnych przedmiotów, podobnie w kościele trynitarskim, gdzie poza tym zabrano też obraz Matki Bożej. Najwięcej zaś srebra znaleziono w kościele ormiańskim - ok. 16,4 kg. Dodatkowo wyszły na jaw inne fakty ukrycia kosztowności. Niektóre z nich znajdowały się w mieszkaniach zaufanych parafian. Na przykład ks. W. Dworzecki, który będąc chorym zalecił swoim parafiankom siostrom Rogozińskim ukryć większość kosztowności u siebie w domu. Inna część kosztowności przechowywała się u parafianina ormiańskiego kościoła pana Paluszka we wsi Hołosków. Księży R. Szyszkę i Walerego Szymańskiego oskarżano zaś za nie wydanie monstrancji i ukrycie innych srebrnych przedmiotów. Por. Сторчовий, Нестеренко, Римсько-католицька Церква на Поділлі, s. 15-16.

${ }_{106}$ Jaruzelski, Z archiwaliów Ministerstwa Spraw Zagranicznych (cz. 2), s. 150-151; APIS, sygn. A. 12. P/6/4/35, k. 198; Kościót katolicki na Ukrainie, s. 53-54; Dzwonkowski, Kościót katolicki w ZSSR, s. 135.

107 Prawdopodobnie za księdzem T. Skalskim, ks. prof. R. Dzwonkowski, jak również N. Rubliowa, błędnie podają, że wyrok ten dotyczył również księdza Feliksa Lubczyńskiego. Zob. T. Skalski, Terror i cierpienie. Kościót katolicki na Ukrainie 1900-1932. Wspomnienia, opr. J. Wołczański, Lublin-Rzym-Lwów 1995, s. 219; Dzwonkowski, Kościót katolicki w ZSSR, s. 138; Бiozpaфії римо-католицьких священників, „3 архівів ВУЧК-ГПУ-НКВД-КГБ”, 2003, № 2 (21), s. 411. Ks. Lubczyński nie przebywał w tym czasie jeszcze w Kamieńcu i nigdy nie był sądzony w sprawie ukrywania kosztowności kościelnych. Por. ДАХО, Р-6193, оп. 12, П- 27379, passim.

${ }^{108}$ Por APIS, sygn. A. 12. P/6/4/35, k. 194-195; Kościót katolicki na Ukrainie, s. 50-51; Jaruzelski, Z archiwaliów Ministerstwa Spraw Zagranicznych (cz. 2), s. 158-163, (cz. 3), s. 443; Сторчовий, Нестеренко, Римсько-католицька Церква на Поділлі, s. 16-17.

${ }^{109}$ Por. Сторчовий, Нестеренко, Римсько-католицька Церква на Поділлі, s. 17.

${ }^{110}$ APIS, sygn. A. 12. P/6/4/35, k. 195; Kościót katolicki na Ukrainie, s. 51.

${ }^{111}$ Por. ДАВО, Р-207, оп. 5, спр. 1, к. 102; Mańkowski, Pamiętniki, s. 352.

${ }_{112}$ Por. ДАВО, Р-207, оп. 5, спр. 1, к. 104; Без “Білих плям”. Документ-свідчення, „Комсо- 
Dzięki jednak interwencji rządu polskiego karę śmierci zamieniono wkrótce na 5 lat więzienia ${ }^{113}$, a po 14 miesiącach przebywania w więzieniu w Winnicy kapłani zostali dnia 2 października 1923 roku amnestionowani ${ }^{114}$. Niestety tego dnia nie doczekał ksiądz Niedzielski, który na skutek choroby zmarł w więzieniu jeszcze w listopadzie 1922 roku $^{115}$. Kapłan ten stał się praktycznie pierwszą śmiertelną ofiarą sowieckiego sytemu represyjnego na terenie diecezji kamienieckiej.

W samym Kamieńcu Podolskim po tym procesie nie zaprzestano kolejnych rabunków kościołów. Na przykład już w pierwszej połowie września 1922 roku rozgrabione zostały grobowce hr. Potockich znajdujące się w podziemiach kościoła dominikańskiego, a w samym kościele przeprowadzono rewizje i zrabowano puszkę, 2 bardzo cenne ornaty oraz kilka dywanów. W katedrze z kolei pozrywano złote blachy z ołtarzy oraz obrabowano bogate grobowce ${ }^{116}$ biskupów kamienieckich. ${ }^{117}$ Kościół katedralny w Kamieńcu ogołocono wówczas ze wszystkich precjozów. Inwentarz tej świątyni sporządzony w 1930 roku nie wymienia już żadnego przedmiotu ze srebra lub $z_{ł o t a}{ }^{118}$. W późniejszych latach wiernym udało się nieco wzbogacić mienie własnego kościoła. Według protokołu z 10 kwietnia 1935 roku widać, że w katedrze przechowywało się różnego rodzaju srebrnych rzeczy ogólną wagą ponad 30 kg i wartości 2147 rubli 50 kopiejek. Między innymi kilka krzyży, kilkanaście relikwiarzy, trybularz, monstrancja i różnego rodzaju mniejsze naczynia liturgiczne. ${ }^{119}$

мольське племя", 18 жовтня 1990 р. (Вінниця), s. 3; Вінниц̧ький капуцииський монастир, s. $88-89$.

113 Zob. Mańkowski, Pamiętniki, s. 352; „Przegląd Katolicki”, 1922, nr 20, s. 319; Бiozpaфiï римо-католицьких священників, „3 архівів ВУЧК-ГПУ-НКВД-КГБ”, 2003, № 2 (21), s. 416, 435.

114 „3 архівів ВУЧК-ГПУ-НКВД-КГБ”, 2003, № 2 (21), s. 435; ДАХО, Р-6193, оп. 12, спр. П-3585, т. 1, к. 19.

115 APIS, sygn. A. 12. P/6/4/35, k. 195; Kościół katolicki na Ukrainie, s. 51; Бiографiï puмoкатолищьких священників, „З архівів ВУЧК-ГПУ-НКВД-КГБ”, 2003, № 2 (21), s. 416. Вłędną datę śmierci księdza Niedzielskiego podaje ks. prof. R. Dzwonkowski. Zob. Losy duchowieństwa katolickiego w ZSSR 1917-1939. Martyrologium, Lublin 1998, s. 370-371.

${ }^{116} \mathrm{~W}$ podziemiach katedry kamieniekciej, które składały się z dziewięciu katakumb, spoczywali między innymi biskupi ordynariusze: Mikołaj Dembowski (†1757), Michał Sierakowski (†1802), Jan Mikołaj Dembowski (†1809), Franciszek Mackiewicz (†1842), Mikołaj Górski (†1855); bp sufragan Adam Orański, szereg członków dawnej kapituły kamienieckiej orazkasztelan wyszogrodzki Bartłomiej Giżycki, starosta bachtyński Krzysztof Romer, komendant Kamieńca Michał Kuczyński z żoną Anną z Ellbertów, komendant fortecy Jan Witt z żoną Marjanną z Lubońskich. Por. K. Iwanicki, Katedra w Kamieńcu, Warszawa 1930, s. 28.

${ }^{117}$ APIS, sygn. A. 12. P/6/4/35, k. 195-196; Kościół katolicki na Ukrainie, s. 51-52.

${ }^{118}$ Spis ten wymieniał jedynie kilkanaście pozłacanych paten oraz jedną pozłacaną monstrancję, prawdopodobnie z białego metalu. Por. J. Wołczański, Inwentarz rzymskokatolickiej katedry pod wezwaniem Apostołów Św. Piotra i Pawła w Kamieńcu Podolskim według stanu z 1930, w: Pasterz i Twierdza, s. 373-383; ДАХО, Р-1454, оп. 1, спр. 13, к. 17-22.

119 Por. ДАХО, Р-1454, оп. 1, спр. 13, k. 23. Spis i rejestr tych rzeczy został sporządzony na podstawie rozporządzenia WUCWK z 23 stycznia 1934 roku „O konfiskacie i przechowaniu srebrnych rzeczy w budynkach modlitewnych”. ДАВО, Р-2700, оп. 2, спр. 25, к. 131. 
Miejscowe władze wykonawcze i partyjne na Podolu pierwsze podsumowanie kampanii rekwizycji kosztowności kościelnych spróbowały dokonać już pod koniec maja 1922 roku. Stanem na 25 maja w całej guberni skonfiskowano ogółem ponad 121 pudów srebra (ok. $1982 \mathrm{~kg}$ ) oraz nieco ponad 83 zołotnika złota (ok. $350 \mathrm{~g}$ ), a poza tym znaczną sumę pieniędzy w srebrze 5364 rubli, 52 rubli $\mathrm{W}$ złocie oraz jeden złoty krzyż z 20 rubinami ${ }^{120}$. W sumie na ten czas na całym Podolu, z wyjątkiem powiatu latyczowskiego i kamienieckiego, zarekwirowano kosztowności z 928 cerkwi, 75 kościołów, 143 synagog oraz 9 klasztorów prawosławnych ${ }^{121}$. Mimo to, władze gubernialne nie były zadowolone wynikiem tej akcji. Na plenum komitetu wykonawczego Podola z 9 czerwca 1922 roku przewodniczący Porajko zaznaczył, że kampania z konfiskaty kosztowności nie całkiem spełniła pokładane w niej nadzieje ${ }^{122}$. Powyższa statystyka niewiele się zmieniła do końca czerwca, gdy prace komisji do spraw konfiskaty kosztowności kościelnych faktycznie zakończono $\mathrm{w}$ guberni podolskiej. Zgodnie z danymi z poszczególnych powiatów na 30 czerwca na Podolu ogółem zarekwirowano kosztowności kościelnych w srebrze na ok. $2128 \mathrm{~kg}$, w złocie ponad pół kilograma oraz ponad 7000 rubli srebrnych i 60 rubli złotych ${ }^{123}$. Najwięcej wartościowych przedmiotów skonfiskowano $\mathrm{w}$ powiatach olhopolskim, jampolskim, winnickim i kamienieckim. Stanowiło to jednak znikomy odsetek (około 4,5 \% srebra i $1 \%$ złota $)^{124}$ od ilości kosztowności kościelnych zarekwirowanych na terytorium całej Ukrainy radzieckiej ${ }^{125}$. Dlatego też nie dziwi fakt niezadowolenia gubernialnych organów wykonawczych.

Niestety nie ma osobnych danych dotyczących Kościoła katolickiego na Podolu. Według szacunkowych obliczeń autora artykułu $Z$ raju bolszewickiego $\mathrm{z}$ każdego kościoła $\mathrm{w}$ diecezji kamienieckiej zabrano przeciętnie po około 3 funta $(1,228 \mathrm{~kg})$ srebra, co w sumie dawało około 100 kielichów i puszek, 5 monstrancji i wiele innych mniejszych rzeczy ${ }^{126}$. Znamy jedynie liczbę kościołów, z których zostały skonfiskowane kosztowności kościelne przez wspomniane komisje. $\mathrm{Na}$ tle innych wyznań przedstawia to tabela $\mathrm{nr} 3$. Brakuje tu jednak danych z powiatu kamienieckiego, gdzie wówczas, nie licząc kaplic, było 15 kościołów rzymskokatolickich. Nie ma tu danych także z powiatu bałckiego (5 kościołów parafialnych), który od 1921 roku został włączony do guberni odeskiej. Niewątpliwie wspomniane wyżej świątynie nie zostały pominięte przez miejscowe komisję do spraw konfiskaty kosztowności. Analizując tę tabelę należy stwierdzić, że rekwizycja kosztowności kościelnych dotknęła praktycznie większość świątyń katoli-

${ }^{120}$ Por. ДАВО, Р-925, оп. 2, спр. 879, k. 15.

121 „Известия”, Винница, 10 июня 1922, № 123 (481), s. 3.

${ }^{122}$ Tamże.

${ }^{123}$ Por. ДАВО, Р-925, оп. 2, спр. 879, k. 18.

124 Obliczenia własne autora.

${ }^{125}$ Zgodnie z danymi Centralnej Komisji do spraw rekwizycji kosztowności kościelnych na Ukrainie według stanu na 24 czerwca skonfiskowano 2850 pudów 30 funtów 3 zołotnika srebra oraz 3 puda 2 funta 28 zołotników złota. Por. Змерзлый, Изъятие иеерковных иеенностей, s. 142. „Известия", Винница, 7 июля 1922, № 146 (504), s. 2.

${ }^{126}$ Por. „Przegląd Katolicki”, 1922, nr 9, s. 131-132. 
ckich. Co najmniej w połowie dekanatów diecezji kamieniekciej (płoskirowski, bracławski, winnicki, jampolski, mohylowski) skonfiskowano kosztowności we wszystkich większych kościołach. W niektórych powiatach (olhopolski, żmeryniecki, bracławski) objęły one nie tylko kościoły parafialne, lecz również filialne i kaplice.

Tabela 3. Ilość świątyń różnych wyznań w guberni podolskiej, w których przeprowadzono rekwizycje kosztowności kościelnych według stanu na 30 VI 1922 roku

\begin{tabular}{|l|c|c|c|c|c|}
\hline \multirow{2}{*}{ Powiaty } & \multicolumn{4}{|c|}{ Skonfiskowano kosztowności } & \multirow{2}{*}{$\begin{array}{c}\text { Liczba kościołów } \\
\text { parafialnych** }\end{array}$} \\
\cline { 2 - 5 } & Cerkwie & Synagogi & Klasztory & Kościoły & \\
\hline Jampolski & 100 & 8 & - & 4 & 5 \\
\hline Olhopolski & 111 & 18 & 2 & 11 & 4 \\
\hline Kamieniecki & - & - & - & $15^{*}$ & 14 \\
\hline Uszycki & 118 & 9 & - & 8 & 15 \\
\hline Bracławski & 119 & 35 & 1 & 8 & 6 \\
\hline Płoskirowski & 96 & 18 & 4 & 12 & 12 \\
\hline Żmeryniecki & 94 & 2 & 2 & 14 & 9 \\
\hline Hajsyński & 35 & 12 & 12 & 5 & 4 \\
\hline Mohylowski & 86 & 34 & - & 5 & 6 \\
\hline Winnicki & 108 & 23 & - & 7 & 7 \\
\hline Latyczowski & 120 & 23 & - & 5 & 7 \\
\hline Lityński & 61 & 6 & - & 2 & 6 \\
\hline Suma & $\mathbf{1 0 4 8}$ & $\mathbf{1 8 8}$ & $\mathbf{2 1}$ & $\mathbf{8 1}(\mathbf{9 6})$ & $\mathbf{9 5}$ \\
\hline
\end{tabular}

* Brak oficjalnych danych z powiatu kamienieckiego. ** Ustalenia własne autora.

Źródło: ДАВО, Р-925, оп. 2, спр. 879, k. 18. 


\title{
DIE BESCHLAGNAHME DER KIRCHENSCHÄTZE IM JAHRE 1922 UND DIE RERAKTION DER RÖMISCH-KATHOLISCHEN KIRCHE IM SOWJETISCHEN TEIL VON PODOLIEN
}

\begin{abstract}
Zusammenfassung
$\mathrm{Zu}$ Beginn der zwanziger Jahre herrschte auf dem Territorium des Sowjetstaates eine schreckliche Hungersnot, die besonders das Wolgagebiet und den Kaukasus betraf. Die bolschewistischen Machthaber in Moskau machten sich diese Tragödie zunutze und erließen am 23. Februar 1922 ein Dekret über die Beschlagnahme der Kirchenschätze, die für den Spezialfonds des Zentralen Hungerhilfskomitees bestimmt werden sollten. Die wirklichen Ziele dieser Konfiszierung waren jedoch völlig andere, und das Dekret selbst lieferte den Machthabern lediglich einen bequemen Vorwand zum Angriff gegen die Kirche. Im Gefolge der Moskauer Regierung fassten die zentralen Exekutivorgane in der Sowjetukraine am 8. März 1922 dann ebenfalls einen solchen Beschluss. Bald darauf entstanden auf dem Territorium des gesamten Staates Kommissionen für die Beschlagnahme der Kirchenschätze, die unter der strikten Aufsicht und Kontrole der Tscheka arbeiten sollten. Beschlagnahmt wurden ausnahmslos alle sich in den Kirchen verschiedener Konfessionen befindende Wertgegenstände. Dem unmittelbaren Beginn der Konfiszierung der Kirchenschätze ging eine groß angelegte Agitationskampagne voraus. Im Gouvernement Podolien begann diese Aktion praktisch schon in der zweiten Aprilhälfte 1922 und dauerte bis Ende Juni. Bis zu diesem Zeitpunkt wurden in Podolien aus insgesamt 1048 orthodoxen Kirchen, 21 Klöstern, 81 anderen Kirchen und 188 Synagogen über 2,1 Tonne Silber, über ein halbes Kilo Gold und etwa 7000 Silberrubel sowie 60 Goldrubel konfisziert.

Von diese Kampagne blieb auch die römisch-katholische Kirche in Podolien nicht verschont, die verglichen mit den anderen Konfessionen den stärksten Widerstand leistete. Die Geistlichen und Gläubigen der Diözese Kamieniec setzten sich ganz entschieden für ihre Kirchen ein, was in der Konsequenz dazu führte, dass einige Priester und Katholiken, die sich der Beschlagnahme widersetzten, verhaftet wurden und ins Gefängnis kamen. Das größte Aufsehen erregte in ganz Podolien und außerhalb seine Grenzen der Einsatz der römisch-katholischen Geistlichen und Gläubigen in Kamieniec Podolski, die offenen Widerstand gegen die Konfiszierungen leisteten. Vier Priester aus Kamieniec und mehrere Gemeindemitglieder wurden damals sogar zum Tode verurteilt, weil sie Kirchenschätze versteckt hatten, aber dieses Urteil wurde dank einer Intervention der polnischen Regierung dann in fünfjährige Gefängnisstrafen umgewandelt. Erst nach einem Jahr gelang es ihnen, ihre Freiheit wiederzuerlangen. Allerdings erlebte P. Antoni Niedzielski, der Pfarrer der Kathedrale von Kamieniec, diesen Tag nicht mehr, da er bereits im November 1922 im Gefängnis von Winnica verstorben war.
\end{abstract}

